Bu makaleye atıfta bulunmak için/To cite this article:

KESER, A. (2021). Modern Arap Şiirinin Yenilikçi ve Öncü İsmi Ahmed Zeki Ebû Şâdî. Atatürk Üniversitesi Sosyal Bilimler Enstitüsü Dergisi, 25 (Özel Sayı), 176-193.

\title{
Modern Arap Şiirinin Yenilikçi ve Öncü İsmi Ahmed Zeki Ebû Şâdî
}

\author{
Adem KESER ${ }^{(*)}$
}

Öz: Arap dünyası, Napolyon'un 1798'de Mısır'ı işgaliyle birlikte Batı kültürüyle ilk teması kurmuş, daha sonra bu kültürle etkileşim içine girmiş̧tir. O zamana kadar durağan bir durumda olan Arap toplumu, bu temas neticesinde Batının çok gerisinde olduğunu fark etmiş ve devlet ricalinin de girişimleriyle her alanda bir kalkınma ve diriliş hareketi başlatmıştır. Bu hareket doğal olarak edebiyat ve şiire de yansımış ve şiirde klasik anlayışın yanı sıra modern bir anlayış da benimsenmiş ve bu bağlamda birtakım şiir ekolleri ortaya çıkmıştır. Bu ekollerden biri de romantizm akımının etkisinde kalan Apollo ekolüdür. Arap şiirine modernleşme yolunda önemli

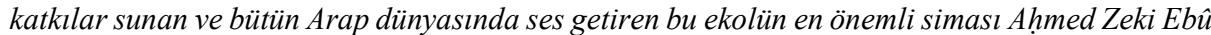
Şâdî'dir.

Ülkemizde Eb̂̂ Şâdî'yle ilgili yapılan çalışmalara baktığımızda daha çok onun Apollo ekolüne olan katkısl, ekol içindeki yeri vb. meseleler üzerinde durulduğunu; ancak şiir örneklerine yeteri kadar yer verilmediğini görüyoruz. Bu çalışmamızda, Apollo ekolünün kurucusu, Arap şiirinin yenilikçi ve öncü ismi olan ve "serbest şiir" olarak bilinen şiir türünü Arap edebiyatına kazandıran Ahmed Zeki Ebû Şâdî̀'yi şiir örnekleri üzerinden ele alarak Arap edebiyatındaki yerini ve șiire olan katkısını ortaya koymaya çalışacağız.

Anahtar Kelimeler: Modern Arap şiiri, romantizm, Apollo ekolü, Ahmed Zeki Eb̂̂ Şâdî, serbest siir.

\section{Ahmad Zeki Abu Shadi, Innovative and Leading Name of Modern Arabic Poetry}

Abstract: Egyptians first contacted with the Western culture after Napoleon's invasion of Egypt in 1798, and from then on, they have interacted with that culture. The Egypt community was stable at that time and with the new interaction they had realized that they were underdeveloped and fell behind the West, so the political leaders have started a development and resurrection movement. That movement normally brought some reflections on literature and poetry, and modern poetry have been preferred instead of classical one with new poetry schools. Apollo society is one of those poetry schools. Ahmad Zeki Abu Shadi is the most important figure of Apollo society who had many supports on Arabic poetry in the process of modernization.

In our country, studies about Ahmad Zeki Abu Shadi mostly mention his support on Apollo society and his position in that society, and in those studies his poems were neglected by the researchers. In this study, we tried to examine Ahmad Zeki Abu Shadi's position in the Arabic literature who is the founder of Apollo society and brought "free verse" to that literature with the examples of his poems.

Keywords: Modern Arabic poetry, Apollo society, Ahmad Zeki Abu Shadi, free verse.

${ }^{*}$ Doktora Öğrencisi, Atatürk Üniversitesi Sosyal Bilimler Enstitüsü Arap Dili ve Edebiyat1 Bölümü (e-posta: ademkeser1981@ gmail.com) DORCID ID. https://orcid.org/0000-0003-25239766

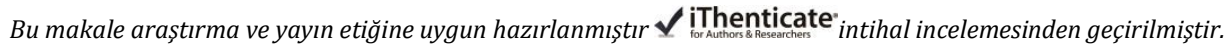


Makale Geliş Tarihi: 27.06.2021

Makale Kabul Tarihi: 23.09.2021

DOI:10.53487/ataunisosbil.958155

\section{Giriş}

Modern Arap edebiyatının doğmasında belki de en önemli olay, 1798 yılındaki Napolyon'un Misır seferidir (Dayf, 1961: 11). Napolyon'un bu seferi, Avrupa tarihinde olduğu gibi İslam tarihinde ve Arap edebiyatında bir dönüm noktası olarak kabul edilir. $\mathrm{Bu}$ sefer, Batının İslam dünyası üzerinde siyasi, ekonomik ve kültürel nüfuzunun başlangıcını teşkil eder. Çünkü Napolyon'un çevresindeki araştırma ekibiyle Mısır'a gelmesi neticesinde Mısır'da yenilik hareketleri başlamış; okullar, gazeteler, opera binası, matbaa, ilmî kurullar, kütüphaneler, kimya laboratuvarları ve rasathaneler inşa edilmişti (ez-Zeyyât, t.y.: 415-416).

Bu durum, 19. ve 20. Yüzyıl Arap edebiyatında gerek şiir gerekse nesir alanında görülen değişim hareketlerinin öncülerinin çoğunlukla Mısır'dan çıkmasına ve Mısır'ın Arapça konuşan diğer ülkelerden daha önce Batıya açılma sürecine girmiş olmasına vesile olmuştur. Napolyon'un Mısır'ı işgali, bazen bir tehdit olarak görülüp nefret edilen, bazen de bir model alınıp hayran kalınan ve her alanda, her anlamda bir dizi radikal dönüşümün yaşandığı süreç olmuştur (Er, 2012: 11).

Modern dönemde değişimin başlangıcında Arap edebiyatçıları, Abbasi dönemi şair ve yazarlarını taklide yönelmişler, daha sonra gerek şekil, gerekse konu açısından klasik dönemin etkisinden sıyrılarak farklı bir anlayış benimsemişlerdir. Batıda öğrenim gören şairler, şiirde modernleşmeyi savunuyor, yeni şiir eleştirileri geliştiriyor ve bu bağlamda bir araya gelerek gruplar oluşturuyorlard1. Bu çerçevede oluşan önemli gruplardan biri de şiirde romantizmin etkisinde kalan ve serbest şiiri gündeme getiren edebi topluluk Apollo grubudur.

Bu bağlamda mevzuyu aydınlatması ve daha anlaşılır kılması açısından modern Arap edebiyatının doğuşunu hazırlayan sebeplere, modern dönemde Mısır şiirine ve Apollo ekolüne yer vererek Arap şiirinin belli bir dönemine damgasını vuran ve bu ekolün kurucusu olan Ahmed Zeki Ebû Şâdî’nin hayatından bahsedip, edebî kişiliğine değinmek yerinde olacaktır.

\section{Mısır’da Modern Arap Edebiyatının Doğuşu}

Milletlerin edebiyat alanında gösterdikleri gelişmelerin belirli bir zaman dilimi içerisinde katettiği mesafeyi incelerken bu zaman dilimi içerisinde yaşamış olan kuşağa ait edebî mahsullerin ortaya konmasında önemli rol oynayan çevrenin bilinmesi gerekir (Yanık, 1991: 1). Çünkü edebiyat, özel ve genel hadiselerle etkilenen toplum hayatının aksettiği bir ayna gibidir (Dayf, 1961: 11). Bu bakımdan yeni Arap edebiyatının doğup gelişmesinde etkili olan, toplumun kültürel ve sosyal hayatına yön veren tarihî olaylara değinmenin konuyu aydınlatacağı muhakkaktır.

Şu bir gerçek ki, Napolyon'un Mısır'ı işgaliyle birlikte Mısır'da başlangıçta Fransız kültürü çok fazla etkili olamamıştı. Daha sonra bazı Mısırlı aydınlar, Napolyon'un 
beraberinde getirdiği çeşitli alanlarda uzmanlaşmış bilim insanlarının çalışmalarına ve deneylerine ilgi duymaya başladılar. O dönemde Avrupa, ilim ve sosyal alanda bir hayli yol almışken Arap ülkeleri henüz başlangıç aşamasındaydı (Savran, 1991: 7-8).

İşgalden sonraki yıllarda özellikle Mehmed Ali Paşa döneminde (1805-1848) Mısır'da geniş çaplı bir eğitim-öğretim seferberliği olmuş, her derecede okullar açılmış (ez-Zeyyât, t.y.: 416) ve Avrupa'ya öğrenci gönderilmeye başlanmıştı. Avrupa'ya giden bu öğrenciler, çeşitli bilim ve sanat dallarında uzmanlaşarak Mısır'ın ilerlemesine ve gelişmesine katkı sağladılar (Heykel, 1994: 27-28). Bu dönemde yapılan diğer yenilikler ise Bulak'ta matbaanın kurulması ve gazetecilikti. Matbaada hükümetin hususi yayınları ve ordunun askerî eğitimiyle ilgili Türkçe broşürler basılmış, Arap, Türk ve az miktarda İran edebiyatından önemli eserlerin neşrine çalışılmıştı (Yanık, 1991: 9-10). Gazetecilikte ise, 1828 yılında el-Vakâa' ‘u'l-Mıșriyye adlı gazete kurularak fasih Arapçanın yaygınlaştırılması amaç edinilmişti (ez-Zeyyât, t.y.: 417).

Mehmed Ali Paşa'dan sonra yerine oğlu İbrahim Paşa geçmiş, kısa bir süre içerisinde ölünce yerine Mehmed Ali Paşa'nın torunu Hidiv Abbas (1848-1854) Mısır valiliğine getirilmişti. Hidiv Abbas devrinde, kalkınma, ilerleme ve gelişme hareketleri durgunlaşmış, Fransız bilim adamları ve uzmanların çoğu ülkeden uzaklaştırılmış, ilkokulların, liselerin ve yüksekokulların çoğu kapatılmıştı (Dayf, 1961: 14-15).

Hidiv Abbas'ın 1854'te ani ölümü üzerine Said Paşa (1854-1863) Misır valisi oldu. Mısır, onunla millî bir anlayış benimsemiş ve Mısırlılar, sivil idarede ve orduda yüksek mevkilere getirilmişti. Batı kültürünü benimsemiş olan Said Paşa, selefi devrinde başlayan eğitim alanındaki gerilemeyi durdurmak için ne yazık ki hiçbir ciddi faaliyette bulunamadı. Devrindeki en önemli hadise, Süveyş kanalının kazılmasına başlanmasıydı (Zeydan, 2012: I/47-48).

Said Paşa'nın ölümünden sonra İsmail Paşa (1863-1879) yönetimi devraldı. Onun döneminde pek çok okul, kütüphane, müze, ilmî cemiyet açılmış, opera binası inşa edilmiş ve Süveyş kanalının yapımı tamamlanmıştı. Mısır halkının yabancılarla kaynaşması, yayın faaliyetlerinin artması, tiyatronun canlılık kazanması, okulların çoğalması, Avrupa ilminin ülkeye aktarılması vb. hususlar dilin gelişmesine ve edebî canlılığa vesile olmuş, Arap dili tamamen öğretim dili haline gelerek telifte de esas kabul edilmişti (Zeydan, 2012: II/50-53).

İsmail Paşa'nın azledilmesinden sonra oğlu Tevfik Paşa (1879-1882) Mısır valisi olmuş, döneminde siyasî krizlere rağmen, eğitim-öğretim faaliyetleri ihmal edilmemiş ve bu alandaki çalışmalara devam edilmiştir (Yanık, 1991: 22-23). Öte yandan Mısır'da Fransız kültürünün yerleşmesinden ve öğretimin Arapça olmasından dolayı millî şuurun uyanmasından endişe eden İngilizler, ülke genelinde eğitim-öğretimi tamamen İngilizceye çevirip bu dili mecburi dil haline getirdiler ve fasih Arapçanın gelişmesini engellemek suretiyle halk ağzının ilmî ve edebî yazı dili olması için uğraştılar (Heykel, 1994: 94-95). 
1871'de Misır'1 ziyaret eden Cemaleddin Afganî (1839-1897)'nin İslam ülkelerine yabancıların müdahale etmelerini önleme hususunda meşhur davetini yapması, 1882'de Arabî Paşa'nın işgalcilere karşı hareket başlatması, Mısr, el-Vatan ve el-Livâ gibi gazetelerde "Mısır Mısırlılarındır" manşetinin atılması Mısır halkında millî mücadele ruhunu pekiştirmiş ve bu çabaların verimli sonuçları alınmıştı. 1919 ihtilali, Arap dünyasında istiklal hareketlerini kamçılamaya başladı. Nihayet 1923'te kabul edilen bir kanunla halk, hürriyet hususunda istediklerinin büyük bir kısmını elde etti. Mısır en sonunda, 19. Yüzyılın sonlarından itibaren mücadelesini verdiği bağımsızlığına 23 Temmuz 1952 ihtilali ile kavuşup sömürgeci güçleri temizledi ve cumhuriyet ilan edildi. İngiliz hâkimiyeti tamamen ortadan kaldırıldı. Ne var ki İngilizler Mısır'ı etkisi altına alan bir kültür bırakarak ülkeyi terk etmişlerdi (Savran, 1991: 14).

\section{Modern Dönemde Mısır'da Şiirin Seyri}

Arap edebiyatında modern dönemin başlangıcı kabul edilen 19. Yüzyılın ilk yarısında Mısır'da Arap şiiri; mana, maksat ve üslup bakımından inhitat döneminin devamı şeklindeydi. Şiirin konuları ise, toplumsal meselelerden uzak, dar çerçeveler içerisinde bayağı bir durum arz ediyordu. Şairlerin şiirleri, sanat ağları ile örülüydü ve gereksiz laf cambazlıkları, muammalı ifadeler, söz sanatlarında aşırıya kaçış vb. hususlar, Arap şiirini, derinlik, uyum ve canlılıktan uzaklaştırarak büyük çapta fonksiyonu olmayan bir sanat türü haline getirmişti. Şairlerin örnek alabilecekleri şahsiyetler olmadı̆̆ 1 için de yapabilecekleri tek şey, aruz sanatını ve nazımlarını kalıba dökmeyi öğrenmek ve öğrendikleri bu sanatı uygulamaya koymaktı. Onların bu tarz şiirlerinde, ne ruh, ne canlılık, ne de gerçek bir duygu mevcuttu. Ayrıca bu dönemdeki şiirlerde görülen tek şey taklitti ve şiirler, bir takım lafzi süslemelerden ibaretti (Khouri ve Algar, 1974: 5).

$\mathrm{Bu}$ dönemde yaşayan şairlerden İsmail el-Haşşab, Hasan el-Attar, Muhammed Şihabuddin, Ali ed-Derviş’in şiirlerine baktığımız zaman, şiirlerinin sanatlarla örülü olduğunu, kalın giysileri bürünmüş bir takım lafzi sanatlardan başka bir şey bulunmadığını, insan ruhunu etkileyecek hiçbir duygunun olmadığını görüyoruz. Doğal olarak bu şiirlerde çağdaş toplum hayatının ruhuna hitap eden bir şey bulmak mümkün değildi (Heykel, 1994: 31).

Öte yandan bu devrede yukarıda ifade ettiğimiz şiir anlayışından ayrı olarak az da olsa başka şiir örnekleri de görmemiz mümkündür. Bunlar her ne kadar bir akım sayılacak kadar yaygın değilse de bu devrenin sonlarına doğru ortaya çıkan ve yeniliğin ilk damgalarını taşıyan şiirlerdir. Mesela Rıfa'a et-Tahtavî ve öğrencisi Salih Mecdî’nin bir takım millî ve kahramanlık şiirleri nazmettiklerini görüyoruz. Bu şiirlerden herhangi biri, bu devrenin şiirleriyle mukayese edildiği zaman, en azından bir yenilik taşıdığı görülür. Zikrettiğimiz bu şiirler, kendilerine ait özellikleriyle askere moral vermenin yanı sıra, vezin çeşitliliği ve zenginliği, parçaları arasında özel uyuma riayet edilmesi, koro halinde söylemeye uygun olması nedeniyle şiir ahenginde bir renkliliğe sahiptir (Yanık, 1991: 31).

19. Yüzyılın ikinci yarısında ise, şairler taklitçi metottan kurtulamamışlar, eski şekiller arasında yalpalamaya devam etmişler, devlet büyüklerine övgüler dizerek şiiri geçim aracı haline getirmişlerdi (Yanık, 1991: 32-33). Bunun yanında, Mahmud Sami 
el-Barudî, Ahmed Şevkî, Hafız İbrahim gibi neo-klasik şairler, ilk önce Arap şiirinin zengin geçmişini araştırıp onun bütün özelliğini ortaya koymaya çalıştılar (Er, 2012: 1314).

Arap şiirinde gerçek anlamda ilk değişiklik, kendini Lübnan asıllı Mısırlı şair Halil Mutran'ın şiirlerinde göstermiştir. Mutran'dan sonra, onun etkisiyle kısmen de İngiliz romantik şair ve eleştirmenlerin etkisiyle Mısırlı yenilikçi şairler Abdurrahman Şükrî, Abbas Mahmud el-‘Akkad ve İbrahim Abdülkadir el-Mazinî yeni bir çığır açtılar. Daha sonra Divan ekolü diye bilinecek olan bu şairler, Wordsworth, Shelley, Burns, Milton Hazlitt, Carllyle, Lee Hunt ve Macauley gibi İngiliz edebiyatının önde gelen isimlerinden etkilenmişlerdi (Brugman, 1984: 98).

Divan ekolünün bu üç şairi, şiire önemli anlamlar yüklüyor; şiirin, varlığın ve bireysel felsefenin ifadesi olması gerektiğine inanıyorlardı. Şiirde beyit bütünlüğünden ziyade, organik bütünlük aramadaki ısrarlarının yanı sıra onlar da Mutran gibi, şiirde duygu ve etkilenmenin önemini dile getiriyorlardı. Ortaya konulmasını istedikleri şiir ise, kişisel şiirdi (Er, 2012: 16-17).

Mısır'da Divan ekolü tarafından geliştirilen romantizm, 1930'larda Arap dünyasında zirveye ulaştı. Arap coğrafyalarındaki Fransız ve İngiliz varlığı, bu ülkelerin tam bağımsızlık mücadelelerini sekteye uğratmış, onların millî umutlarını ve heveslerini kırmıştı. Bu durum genel bir hayal kırıklığı, kötümserlik ve umutsuzluk havası meydana getirmiş ve Arap şairlerin romantik şiirlerinde kendini göstermişti (Er, 2012: 21-22).

Divan ekolünün modern Arap şiirine belki de en önemli katkısı, bu şiirde büyük bir çı̆̆ır açan, neredeyse dönemin bütün Arap şairlerinin ilgi ve faaliyet odağı haline gelen, Arap romantizminde büyük bir açılım yapan ve günümüze kadar etkileri devam eden Apollo ekolüne zemin hazırlamış olmasıdır (Yalar, 2003: 97). Bu itibarla Ahmed Zeki Ebû Şâdî’nin başını çektiği bu ekole ayrı bir başlık açmak yerinde olacaktır.

\section{Apollo Ekolü}

Modern Arap şiirinin 20. Yüzyılın ilk çeyreğinden itibaren şekil ve konu bakımından gelişme göstermeye başlaması, bu süreçte modernleşmeyi savunan ve yeni bir şiir anlayışı getiren ekollerin ortaya çıkmasını sağlamıştır. Bu süreçte ortaya çıkan ekollerden biri de 1930'lu yıllarda modern Arap şiirine damgasını vurmuş olan Apollo ekolüdür.

Apollo grubu ilk olarak 12 Ekim 1932'de Ahmed Şevkî'nin öncülüğünde toplanmış; ancak Ahmed Şevkî'nin dört gün sonra ani ölümü üzerine grup üyeleri Halil Mutran'1 Apollo grubuna başkan olarak seçmişler, genel sekreterliğe Ebû Şâdî’yi, başkan vekilliklerine de Ahmed Muharrem ve İbrahim Nacî'yi getirmişlerdi. Ali Mahmud Taha, Hasan el-Kayatî, Mahmud Sadık, Mahmud Ebu'l-Vefa, Sadık Anber gibi dönemin ünlü şair ve eleştirmenleri de kurucu ve yönetim kurulu üyeleri arasında yer almışlardı (Hafacî, 1992: 55). Grubun diğer önemli şairleri ise, Ali Mahmud, Muhammed Abdulmu'tî el-Hemşerî, Suriyeli Ömer Ebu Rîşe, Lübnanlı İlyas Ebû Şebeke, her ikisi de genç yaşta yirmi beş yaşındayken ölen Tunuslu Ebu'l-Kasım eş-Şabbî (1909-1934) 
ve Sudanlı Yusuf Beşir et-Ticanî (1912-1937)'dir. Grubun kurulmasının ardından Mısırlı romantikler, edebî ürünlerini halka ulaştırmak için yayın organına ihtiyaç duymuşlar, 1932 Eylül'ünde Ebû Şâdî öncülügüünde, Abullû "Apollo" dergisini çıkarmışlar ve Tunus'tan eş-Şabbî de bu dergiye şiirleriyle katkıda bulunmuştur (Er, 2012: 22).

Şiirle haşır neşir olan birçok şairi ve yazarı bir araya getiren Apollo ekolü, Mısır'da ve diğer Arap ülkelerinde yaşayan insanları, genelde modern edebiyat, özelde de şiir düşüncesi üzerine yeni bir başlangıca davet etmiştir. Öte yandan derginin, Arap dünyasında şiir ve şiir eleştirisi üzerine yoğunlaşan ve bu amaçla yayınlar yapan ilk dergi olması münasebetiyle edebî değeri büyüktür. Ekolün esas amaçlarını ise şu şekilde özetlemek mümkündür:

a) Arap şiirinin düzeyini yükselterek, şairlerin çabalarını bu tarafa yönlendirmek,

b) Şiir dünyasındaki yenilikleri savunmak,

c) Şairlerin toplumsal, maddî ve edebî seviyelerini yükselterek saygınlıklarını artırmaktır (Kabbiş, 1971: 234).

Apollo grubu, belirlediği bu amaçlar doğrultusunda diğer şiir gruplarından farklı bir çizgide olduğunu ve bu grubun kendine has niteliklerini ve özelliklerini belirlediğini göstermiştir. Ayrıca konu ve meselelere bakış ve yaklaşım açısından, görüşleri arasında benzerlik bulunan şair ve yazarların oluşturduğu bir birlik haline gelmesiyle "grup" olarak ortaya çıkan bu oluşumun zamanla bir "ekol" halini aldığını gözlemiyoruz (Çakır, 2013: 25).

Arap dünyasında şiir ve şiir eleştirisi üzerine yoğunlaşan ilk dergi olma özelliği taşıyan Apollo dergisinin Mısır başta olmak üzere diğer Arap ülkelerinde edebiyat, eleştiri ve şiir alanında büyük bir yankı uyandırmıştır (Hafacî, 1992: 55). Ekolün yayın hayatı olan bu dergi, 1932 yılı Eylül ayında ilk sayısını çıkarmış ve 1934 yılı Aralık ayına kadar devam etmiştir. Dergi, toplamda 28 sayı olarak yayımlanmıştır (Dayf, 1961: 70).

Apollo dergisi, 1934 yılının Aralık ayında çıkan son sayısından sonra bir daha görünmese de, derginin şiir dünyasında oluşturduğu havanın etkileri sürmeye devam etmiştir. Derginin iki yıl, üç ay gibi bir yayın hayatı olmasına rağmen Arap edebiyatında hâlâ belli bir saygıyla anılıyor olması, kurucuların kendilerine önemli misyonlar yükleyerek, iddialı çıkışlar yapmaları sayesindedir. Misyonlarını büyük bir coşkuyla tanıtmış, kendilerini şiir ve şiir eleştirisi alanında farklı bir yere oturtmuş olan grup üyeleri, ister bu misyonu yerine getirmiş olsunlar, ister yerine getiremedikleri için eleştirilsinler dönemin diğer edebiyatçılarından farklı bir adım atmışlardı. Üstelik Apollo dergisinde yayımladıkları gerek şiirler, gerekse eleştiri yazıları, onların samimi düşüncelerinin ve gerçek duygularının ifadeleriydi (Adalar, 2007: 67-68).

\section{Ahmed Zeki Ebû Şâdî’nin Hayatı}

Modern Arap edebiyatında serbest nazımın öncüsü ve Apollo ekolünün kurucusu olan Ahmed Zeki Ebû Şâdî, 9 Ocak 1892'de Kahire'de doğdu (el-Fahurî, 1986: 632633). Babası Muhammed Ebû Şâdî, milliyetçiliğiyle meşhur olmuş, iyi bir hatip ve avukattı. Annesi Emine Hanım ise şiir yazan ve okuyan birisi olup, şair Mustafa Necip'in 
de kız kardeşidir. Ebû Şâdî, edebî bir çevrede edebiyat ve şiir sevgisiyle büyüdü (Dayf, 1961: 145). Ebû Şâdî, ilk ve orta öğrenimini memleketinde tamamladı. Bu esnada babasının Kahire'deki edebî sohbetlerinden yararlandı. Henüz on üç yaşında iken babasının çıkardığı ez-Zâhir dergisinde nesir ve şiir denemeleri yayımlandı. On altı yaşında nazım ve nesir türünden örnekler içeren ilk mecmuasını Kațatün min yerâ ' fi' $l$ edeb ve 'l-ictimâ ' adıyla çıkardı. Babasının sohbetlerine devam eden Ahmed Şevkî, Hafız İbrahim ve Halil Mutran gibi devrin en ünlü şairleriyle tanışma imkânı buldu ve Mutran onu öğrencisi olarak kabul etti. 1910 y1lında çocukluk ve gençlik şiirlerini içeren ilk divanı Endâ' 'u'l-fecr' 'i yayımladı (Yalar, 2016: Ek-1/373-374).

Ebû Şâdî, orta öğrenimini tamamladıktan sonra 1912'de tıp eğitimi için İngiltere'ye gitti ve orada on yıl kaldı. İngiltere'de kaldığı on yıl içerisinde İngiliz edebiyatına dair pek çok eseri inceledi ve birçok başyapıtı tercüme etti (Kabbiş, 1971: 608). Ayrıca, iç hastalıkları, mikrobiyoloji ve bakteriyoloji alanlarında uzmanlık aldı. İki yıl peş peşe bakteriyoloji dalında Londra'nın ünlü Saint George Üniversitesi Hastanesinden onur sertifikası ile Web ödülünü kazandı. Bunlardan başka arıcılık, tavukçuluk ve resimle ilgilendi (Yalar, 2016: Ek-1/373-374).

1922 yılında Mısır'a dönen Ebû Şâdî, çok geçmeden Mısır Arıcılık Kulübünü kurdu. Ertesi sene Kahire Üniversitesi, Tıp Fakültesinde dekan vekilliği yaptı. Memleketu'nNahl, ed-Decâc, eș-Șinâ 'atu'z-Zira 'iyye adıyla çeşitli dergiler yayımladı. 1932 yılında Apollo grubunu kurdu. Grubun yayın organı olarak Apollo dergisini çıkaran Ebû Şâdî, iki yıl yayın faaliyeti olan dergiyi ekonomik sıkıntılar yüzünden Aralık 1934'te son sayısının ardından kapattı. Daha sonra el-Edebî ve el-İmâm adlı iki dergi çıarttı. Fakat bu dergiler, Apollo dergisinin yakaladığı tiraja ulaşamamış, kısa zamanda unutulup gitmiştir (Adalar, 2007: 69).

Ebû Şâdî, hanımı öldükten sonra Amerika Birleşik Devletleri'ne göç etmeye karar vermiş ve 1946 'da İskenderiye'den New York'a gitmiştir. Oradaki Mehcer şairleri topluluğuna katılmak istemiş; fakat kabul görmeyince Suudi Arabistan ve Eritre'nin Birleşmiş Milletlerdeki delegasyonları nezdinde danışmanlık görevi yapmıştır. Ardından New York'taki Asya Akademisi'ne öğretim üyesi seçilen Ebû Şâdî, bu sırada Mehcerdeki Arapça gazetelerde makaleler yayımladı. New York'ta Râbıtatu Minerva adıyla bir edebiyat topluluğu kurdu ve bu topluluğun genel sekreterliğini üstlendi. Ayrıca New York'ta el-Mektebu'l-edebiyyu'l-Mıșrî adıyla bir büro açıp üniversite derslerini ve edebiyatla ilgili çalışmalarını burada yürüttü. Daha sonra bir süre önce evlendiği İtalyan asıllı Amerikalı eşiyle birlikte Washington'a taşındı. Ancak beynindeki kan pihtılaşması yüzünden 12 Nisan 1955 tarihinde vefat etti ve Maryland eyaletinde defnedildi (Yalar, 2016: Ek-1/373-374).

\section{Edebî Kişiliği ve Şiirlerinden Örnekler}

Modern Arap edebiyatında nesirsel bir ritme değil de ölçüye dayalı bir serbest vezinle yazmaya dair ilk ciddi teşebbüsü, Ahmed Zeki Ebû Şâdî gerçekleştirmiştir. Genelde modern Arap edebiyatının, özelde ise modern Arap şiirinin yenilikçi ve öncü isimlerinden biri olan Ebû Şâdî, çok yönlü bir ilmî ve edebî kişiliğe sahipti. Kişiliğinin 
oluşması ve gelişmesinde Cahız, Ahmed Şevkî, Hafız İbrahim, Halil Mutran gibi yerli ve John Keats, Percy Bysshe Shelley, Lord Byron, William Wordsworth, Charles Dickens gibi yabancı şairler etkili olmuştur. O, şiirsel formları deneme konusunda en cesur Arap şairlerinden birisidir diyebiliriz. Ebû Şâdî, İngiliz edebiyatından oldukça etkilenmiş, çağdaş İngiliz ve Amerikan şiirinin gelişimi alanında kendisini geliştiren başarılı bir öğrenci olmuştur (Ceylan, 2015: 188).

Modern Arap şiirinde Ebû Şâdî’yi yenilikçi ve öncü kılan maddeleri ise şöyle siralamamız mümkündür:

a) Edip bir ailede doğup büyümesi,

b) Edebiyat ve şiirde Halil Mutran'1 kendisine örnek alması,

c) Değişik şiir ekollerinin tesiri,

d) Batılı şairlerin etkisi,

e) Derinlemesine İngiliz, Amerikan ve Mehcer edebiyatını incelemesi (Islam ve Hossain, 2020: 5-6).

Batı edebiyatının geniş kültürü Ebû Şâdı̂’ye anlatı, lirik ve tiyatrosal olan realist, romantik ve sembolik akımlardaki şiir türlerini bilmesini sağlamıştır. Daha sonra Ebû Şâdı̂’nin, bu türlerin ve akımların etkisinde kalmaya devam ettiğini ve bu akımlar içerisinde romantik akımın onun üzerinde baskın olduğunu ve hayatına dair birçok koşulun onu sanatsal yaşama ittiğini görüyoruz. Ebû Şâdî, 20. Yüzyılın başında bu akımından etkilenen şairlerle erkenden iletişime geçmiştir. $\mathrm{Bu}$ şairlerin en önemlilerinden birisi, hocası diye bilinen Halil Mutran'dır (Dayf, 1961: 148).

Ebû Şâdî, gençliğinde Zeynep adında genç bir kıza âşık olur; ancak kız, onu terk eder. Kızın Ebû Şâdî'den gidişi, onun kalbinde acıların yayılmasına ve ömrümün sonuna kadar sürecek olan bir şarkı olmasına sebep olur. O, tabiatta ve eski efsanelerde teselli arayan, acıyla, kederle ve yoksun bir aşkla yaşamaya devam eder (Dayf, 1961: 148). Âşık olduğu Zeynep'e adını taşıyan divanda şöyle seslenir:
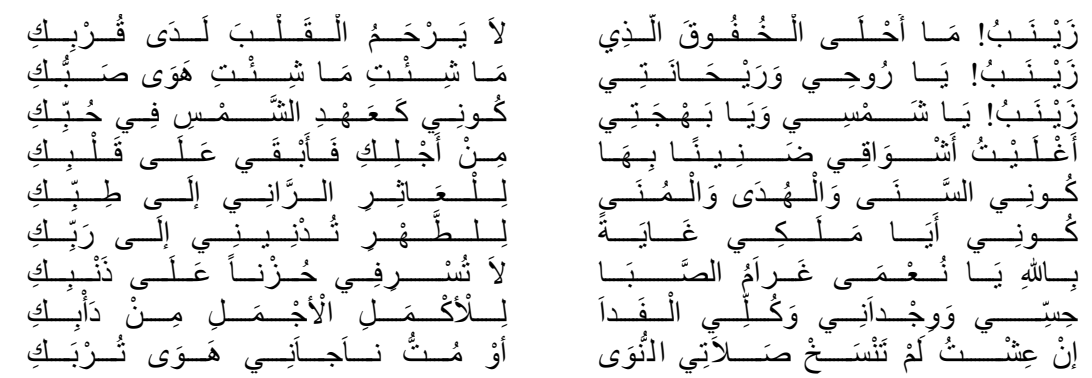

Zeynep! Senin yanındayken kalbimi yerinden söken bu kalp atışı ne kadar da tatll!

Zeynep! Ruhum benim, reyhanım benim! Sen aşı̆̆ının aşkını istemedin istemedin!

Zeynep! Ey güneşim ve sevincim! Aşkında güneşin vefası gibi vefalı ol.

Sana olan kıskançlığım yüzünden arzularımı tutuşturdum senin için kalbinde ebedî kalacă̆ım. 
Hastalanıp seninle şifa bulmak isteyen için ışık ol, rehber ol, arzu ol!

Ey meleğim! Beni senin rabbine yaklaştıracak temizlik için gaye ol!

Allah aşkına ey mutluluğum, gençlik aşkım! Günahından dolayı çok üzülme!

Bütün özverim, hissiyatım ve coşkum senin en güzel huyuna feda olsun!

Yaşarsam dualarımın özü silinmez, ölürsem de senin toprağının arzusu kurtuluşum olur (Ebû Şâdî, 2017: 29).

Onun ruhundaki derin hüznü artıran şeylerden biri de İngilizlerin tahakkümü, zulmü ve baskısı nedeniyle vatanında hissettiği mutsuzluktur. Bahsettiğimiz bu durumlar, onu özensiz şiir yazmaya sevk etmiştir. Özensiz şiir yazmasına bir diğer etkense sanatındaki aceleciliğidir.

Ebû Şâdî'nin geniş kültürü ve şiirsel yetenekleri Allah'ın bir lütfudur diyebiliriz. Fakat Ebû Şâdî aceleci birisiydi. Hayatta ve şiirinde bir yerde durmaz, daldan dala atlardı. Bu hız, eserlerinin manasında sığlığa düşmesine ve kendisiyle fikir ve hayal arasındaki farklı üslupları iyi kullanmasına engel olmuştur. Bu sebeple, çok daha sonra verdiği bazı eserler hariç, şiirlerinin çoğu zihin parıltısından mahrumdur. Bu sadece şiir yazmadaki hızından dolayı değil, ilmî hayatındaki karakteristik yapısından dolayı ilgisini, şiirin farklı alanlarına yönelttiği içindir. Ayrıca bu durum, onun çok yönlü birisi olduğunu gösterir. $\mathrm{O}$, doktordur, bakteriyologdur, tavuk ve arı yetiştirmekle uğraşır, değişik gruplar kurar, ilmî ve edebî dergiler yayınlar. Ebû Şâdî, şiirindeki bu özelliğiyle hikâyesel şiir, dramatik şiir, hüzünlü romantik şiir, mistik şiir, öğüt veren şiir, felsefi şiir, realist şiir, sembolik şiir, mürsel şiir ve özgür şiirle uğraşma gayreti içine girmiştir (Dayf, 1961: 148-149).

Ebû Şâdî, sadece şiirle yetinmemiş, resim ve müzikle de ilgilenmiştir. Başka şeylere olan meylini artırmıştır. Şöyle ki bir elinde neşter, mikroskop ve bilimsel dergiler; diğer elinde kâlem, kuş tüyü, müzik aleti ve edebî dergiler... Laboratuvar sesi, arı uğultusu ve kendi sesinin yankısı şiir yazarken ona ilham vermiştir.

Ebû Şâdî, ilk olarak Endâu'l-Fecr (Sabah Şebnemi) adlı divanını yayımladı. Onu yayımladığında henüz on sekiz yaşındaydı. O eserinde, Ebû Şâdî’nin erken romantik eğilimi net bir şekilde görülür. Şöyle ki, onun siyasî ve sosyal problemleri göz ardı etmeden, sevgiye, tabiata ve ikisinin yankısına yer verdiğini görüyoruz. Nitekim o, Endâu' 'l-Fecr divanında "Hayâtâni" adlı kasidesinde duygularını şöyle dile getirir (Dayf, 1961: 149):

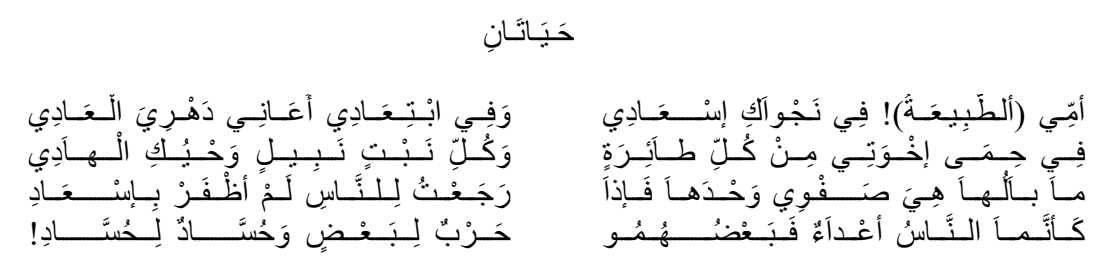




\section{Íki Hayat}

Ey tabiat ana! Seninle söyleştiğimde mutlu oluyorum ve senden uzaklaşınca acımasız zamanıma katlanıyorum.

Senin yol gösterici ilhamın vardır bütün kuşlardan ve bütün soylu bitkilerden olan dostlarımin korusunda.

Ne oluyor ki onlar tek başlarına beni durultuyorlar, insanlara döndüğ̈̈̈mde mutluluğu bulamıyorum.

Sanki insanlar düşman gibidir; kimi kimileriyle savaşıyor, kimileri kimilerini klskanıyor. (Ebû Şâdî, 2013: 15).

Onu okumaya başladığımızda üslubunda, manalarında ve hayal etmedeki zayıflığı hissediyoruz. Bunun sebebi, onun hâlâ genç ve şiir yazma hususunda henüz yeteri kadar ustalaşmamış olmasıdır (Dayf, 1961: 149). Yine o, Endâu'l-Fecr divanında dünyaya hüzünlü bir bakış açısıyla bakar ve duygularını şöyle dile getirir:

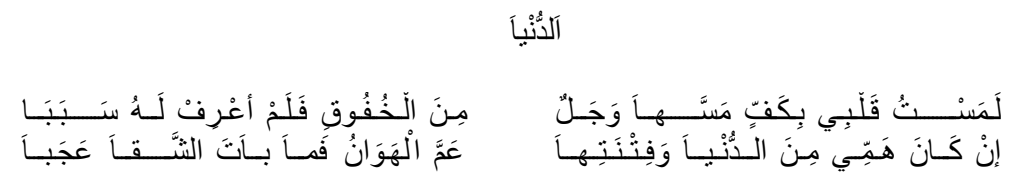

Dünya

Kalbime çarpıntıdan kaynaklanan bir korkunun dokunuşu gibi dokundum ve ben onun sebebini bilemedim.

Eğer benim kederim dünyadan ve onun sınamasındansa alçaklık yaygınlaşmıştır ve artık mutsuzluk şaşılacak bir şey değildir. (Ebû Şâdî, 2013: 21).

Ebû Şâdî, 1912 yılında İngiltere’ye gider ve 1922 yılında geri döner. Orada, İngiliz edebiyatına dair pek çok eseri inceleme firsatı bulur (Islam ve Hossain, 2020: 4). Çok geçmeden divanları ve manzum eserleri yağmur gibi birbirini takip eder. Divanlarında ilk ortaya çıkan 1924 yılında neşrettiği Zeyneb 'tir. Aşk ve tabiat, bu divanın ana eksenidir. Onda muvaşşah, dubeyt ve aşk şiiri kalıplarını öğreniyoruz. Zeynep'te şiir kalıplarını bunlarla yenilemeye uğraşır. Zeynep'teki en iyi kasidelerinden olan "elHilmu'ṣ-Ṣâdı̣”" kasidesi şu şekilde başlamaktadır:
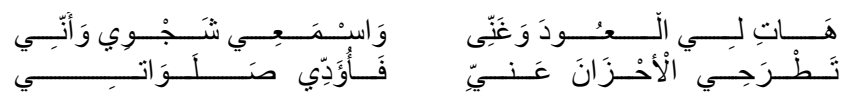

Bana udu getir ve şarkı söyle! Benim kederimi ve iniltimi dinle!

(Ki) Sen hüznümü ortadan kaldırırsın, ben de sana dualarımı gönderirim.

Ertesi sene aynı ezgiyle yazdığı Enîn ve Renîn ve eş-Şi 'ru'l-Vicdân adında iki divan neşreder. O iki eserde de millî duygular ön plandadır. Aynı sene Mıșriyyât divanını yayımlar. O divanda ise, zalim İngilizlerden kurtulmak için Mısırlıların azmini harekete 
geçiren kendi millî duygularını tasvir eder. Çok geçmeden 1926 senesinde Vatanu'lFir 'avn (Firavun'un Ülkesi) divanını yayımlar. Bu divanda ise, eski Mısır'1, Mısır'ın ihtişamını, onun eski eserlerini ve önderi firavunu ön plana çıkarır. Aynı sene, büyük divanı eş-Şefeḳu'l-Bâkî (Ağlayan Günbatımı)'nı çıkardığını görüyoruz. Bu eser, onun kendi serbest şiirinin ilk örneğidir diyebiliriz. Bin sayfadan fazla olan bu eser, Ebû Şâd’’nin ve başka şairlerin şiirle alakalı çeşitli makaleleri kapsadığını, ilaveten bu divanda Ebû Şâdî’nin bazı hikâyeler yazdığını, İngilizce bazı şiirler çevirdiğini, mürsel şiirden ve hür şiirden bazı manzumeleri zikrettiğini görüyoruz. Ayrıca şiirlerinin bir bölümünde dünyayla ilgili haberlerin çoğunu yorumlamış ve şiir yazmaya meylini engelleyen mesleğinin yükünden dert yakınmış, ancak kazandığı gözlem kabiliyetlerinin şiirine katkı sunduğunu itiraf etmiştir. Bu sebeple "Mikroskop"a has Refîkî el-Keşşâf adını verdiği bir şiir yazmış ve bu şiirde mikroskobunu övmüştür (Dayf, 1961: 149-150).

Ebû Şâd’̂’nin şiir yazma kabiliyeti üst düzeydeydi ve o, bütün gözlemlerini şiir haline getirdi. Suk̂utu'l-Celîd, Hadîsu'l-Bahr, Suhbetu'l-Âlâm gibi İngiltere'de yazdığ 1 şiirlerinden bir bölümüne bu divanda yer verdiğini görüyoruz. Yine önceki çalışmalarına benzer şekilde ulusal özlemlerini ve millî duygularını gerek Danşevey anısına gerekse "Yevmu't-Telli'l-Kebîr"in anısını canlandırmak, Fas kırsalı kahramanı Abdülkerim'e selam vermek ve $1925^{\prime}$ te Fransızların toplarla bombaladığı Şam felaketinin acısına göndermede bulunmak gayesiyle eş-Şefeku'l-Bâkî'yi ortaya koyar ve İngiliz sömürgeci şair Kepling'i susturarak ona şöyle cevap verir:

“ Doğu doğudur, Batı batıdır ve ikisi asla buluşmayacaklar!”

Ebû Şâdî’nin bu durumu, çoğu zaman siyasî olaylarla ve pek çok güncel meselelerle ilişkilendirdiğini görüyoruz. Sa'd Zağlul vefat ettiğinde ona özgü yazdığ mersiye içeren bir broşür yayımlamıştı. Buna ilave olarak Sa'd Zağlul'un kırkıncı ölüm yıldönümünde et-Turâsu'l-Hâlid (Ölümsüz Miras) başlıklı başka bir mersiye daha yazdı. Büyük divanı olan eş-Şefeku 'l-Bâkî̀nin neşrini bitirir bitirmez Vahyu'l- 'âmm divanını yayımlamak için hazırlık yaptı. Her sene bu isimle bir divan yayımlayacağını duyurdu. 1931 yılında onun önceki divanlarında gördüğümüz aynı niteliğe sahip Eşsi “â ve Ẓllâl (Işıklar ve Gölgeler) divanını yayımladığını görüyoruz. Bu divanda "el-Ḥubb" (Sevgi) kasidesine yer verir ve şöyle der (Dayf, 1961: 150):

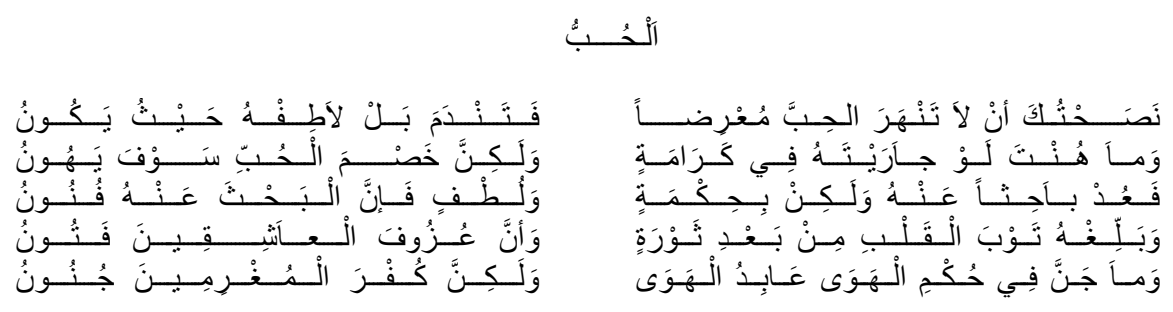


Sevgi

Ben sana sevgiliye baskı yaparak azarlayıp da pişman olmamanı öğ̈̈tledim, nerede olursa olsun ona hoş davran dedim!

Sen ona saygı ölçüsünde davranırsan küçülmezsin, fakat sevginin hasmı mutlaka alçalacaktır!

Aşkı araştırarak aşka yeniden başla; fakat bu lütufla ve şefkatle olsun! Çünkü onu araştırmak sanattır.

Kalbin isyandan sonraki pişmanlı̆̆ını ve âşıkların nağmelerinin baştan çıkardı̆̆ını ona ulaştır!

Aşkın kanununda aşkın kölesi delirmez, fakat âşıklara nankörlük deliliktir. (Ebû Şâdî, 2013: 21).

$\mathrm{O}$, sık sık bazı dünya ressamlarının bir resmini alır, konu hakkındaki düşüncelerini analiz eder. Ayrıca bazı Batılı şairlerin parçalarını ve manzumelerini tercüme eder, bazen tercüme ettiği şeylerin aslını belirtir bazen de bazı kasidelerine Arapça ve İngilizce adlar verirdi.

1933 senesinde ise eş-Şu 'le (Meşale) adlı divanını çıkarır ve o divanda "Kenzu'lHubb” (Sevgi Hazinesi) kasidesine yer verir ve şöyle seslenir (Dayf, 1961: 150-151):

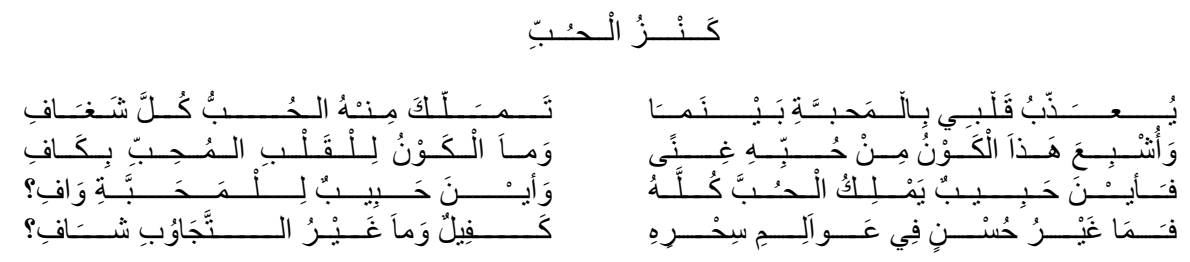

Sevgi Hazinesi

Kalbim aşktan acı çekiyor, aşk kalbimin her tarafinı sarıp ele geçirdiğinde,

Bu âlem onun aşkıyla dolup taştı; fakat seven kalp için bu âlem yetmiyor.

Nerde bütün sevgiye sahip olacak sevgili! Nerde sevgiye vefa gösterecek sevgili!

Onun büyülü âleminde güzellik dışında bir kefil ve olumlu cevap dışında bir şifacı yoktur. (Ebû Şâdî, 2013: 21). 
Onun, aynı sene Atyâfu'r-Reb̂̀` (Bahar Hayalleri) divanını çıkardığını görüyoruz. Bu iki divanda, tabiat, Mısır ve Yunan mitolojisinin en güzel örneklerini toplu bir şekilde takdim eder, millî hedeflerini unutmaz ve millî duygularını dile getirir. Birinci divanındaki en güzel kasidelerden biri "en-Nâs" kasidesidir ve o kasidede insanların birbirleri ile olan mücadelelerini ve düşmanlıklarını tasvir eder. İkinci divanda "Fennân" kasidesini öğreniyoruz ve o kasidede sevgilisine olan sonsuz aşkını aşağıdaki şekilde tasvir eder ve şöyle der:
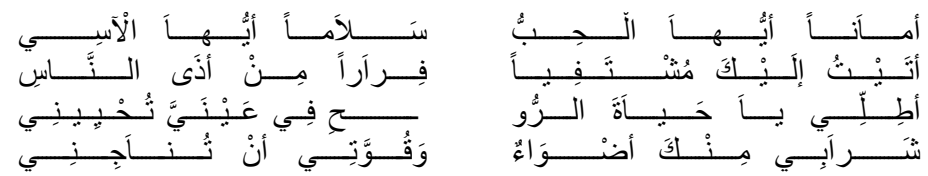

Sana sığındım ey sevgili! Selam olsun sana ey hüzünlü kişi!

Derman için sana geldim insanların eziyetinden kaçarak,

Gözümün nuru gözlerime yukarıdan cemalini sarkıt ki bana hayat veresin.

Sende tattı̆̆ım şeyler beni aydınlatır... Gücüm seninle konuşmaktır.

Aynı konu ve mazmunla 1934 senesinde $e$-Yenbû' (Pınar) divanını çıkarır. Ebû Şâdî, bu divanda arkadaşı ve aynı zamanda grubun üyelerinden biri olan İbrahim Naci'ye şöyle seslenir (Dayf, 1961: 151):

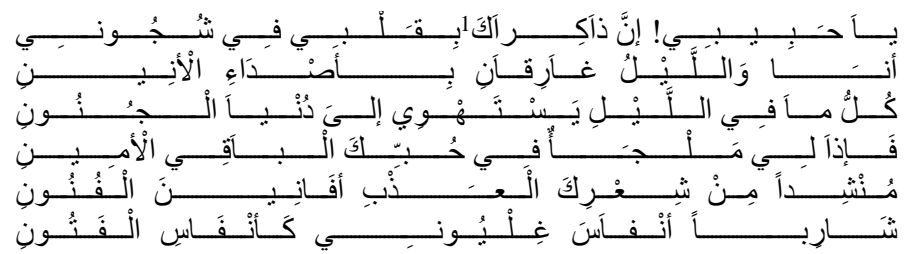

Ey dostum! İki hatıran hüzünlü olarak kalbimde,

Ben ve gece... Iniltilerin yanklsiyla boğuluyor,

Gecedeki her şey cinnet dünyasina çekiyor,

Bir de baklyorum ki, güvenilir ebedî sevginde bir sı̆̆ınağım var.

Tatl şiirinden türlü türlü şiirler okurken,

Fettan birisinin nefesleri gibi pipomu nefes nefes çekerken.( Ebû Şâdî, 2013: 42).

1935 yılında aynı hislerle aşk, tabiat, eski efsaneler ve hayat sahneleri gibi konulardaki Fevka'l-'Ubâb (Dalgalar Üstünde) adlı divanını yayımlar. Bundan dolayı onunla ilgili eleştiriler artar. Bir süre şiir yazmaya ara verir. Fevka'l-'Ubâb adlı divanında ölümle ilgili duygularını şöyle dile getirir (Dayf, 1961: 151):

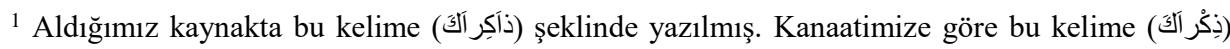
şeklinde olmalıdır. 


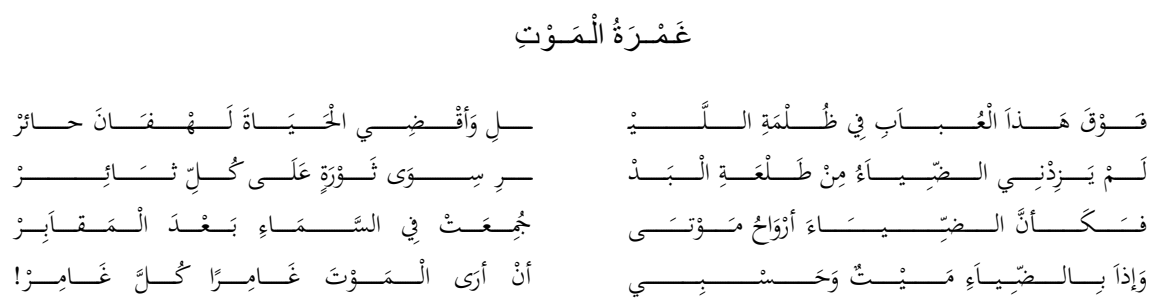

\section{Ölümün Siddeti}

Gecenin karanlığında bu taşkin selin üstündeyim ve bu hayatı özlem dolu ve şaşkın bir şekilde geçiriyorum,

Ayın doğuşundan oluşan ışık, ben de bütün başkaldırılara başkaldırmak dışında bir şey artırmiyor.

Sanki ışlk ölülerin ruhlarl gibi, kabirden sonra gökyüzünde toplanmış.

O da ne! Işılkta da ölüm varmış, bütün gafilleri alt eden ölümü görmek bana yetiyor. (Ebû Şâdî, 2013: 30).

Ebû Şâdî’nin 1942'de yayımladığı 'Avdetu'r-Râ‘̂ (Çobanın Dönüşü) adlı divanında hâlâ mürsel şiir hakkında düşündüğünü ve bazı kasidelerini onun çerçevesinde nazmettiğini; ayrıca Hilmu'l- $\breve{G} a d$ (Yarının Rüyası) adlı eserinde de örnek insanı hayal ettiğini görüyoruz. Yine bu divanda, önceki divanlarında olduğu gibi Mısır halkının bilincini uyandırmaya, "Hidâdu'l-Kuṭn" kasidesinde olduğu gibi ahlaksız yöneticilere karşı ve halkın kutsal haklarını elde etmeleri için onları harekete geçirmeye uğraşır ve kasidede şöyle der:
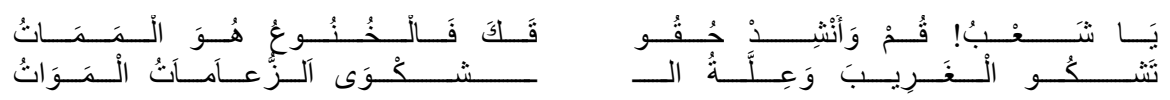

Ey halk! Kalk ve hukukunu haykır! Boyun eğmek ölmek demektir.

Sen garipten şikâyet ediyorsun, oysa şikâyetin nedeni ölü liderliklerdir.

Daha sonra Amerika'ya gider ve 1949 senesinde Mine's-Semâ (Gökyüzünden) divanını yayımlar. O divanda, oradaki denizden, tabiattan ve hayattan bahseder. Mine'sSemâ' da yer verdiği bir kasidesinde duygularını şöyle ifade eder (Dayf, 1961: 151-152): 

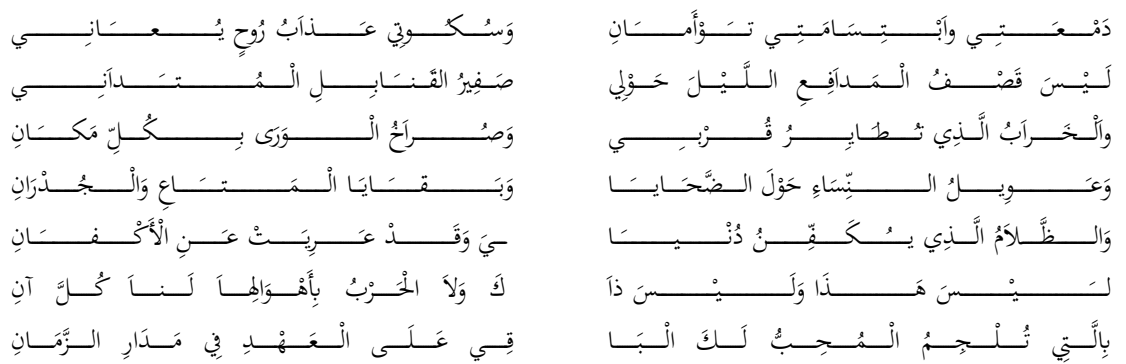

Gözyaşım ve gülümsemem ikiz kardeştir, susmam ise acı çeken bir ruhun azabıdır.

Ne geceleyin çevremde atılan top gülleleri, ne yaklaşan bombaların ıslıkları,

Ne yakınımda uçuşan harabeler, ne insanların her yerde attı̆̆ çı̆glıklar,

Ne kadınların kurbanların çevresindeki feryadı, ne eşyaların ve duvarların kalıntıları,

Ne bütün kefenlerden soyunmuş dünyamı kefenleyen karanlik,

Ne bu ne de şu, ne de her an tehlikeleriyle karşı karşıya olduğumuz bu savaş,

Hiçbiri dünya durdukça sana sevgi duyanı dizginleyemez (Ebû Şâdî, 2013: 66).

Bunlardan ayrı olarak, onun Batı edebiyatlarının incelikleri hakkında bilgi sahibi olması ve hocası Halil Mutran'ın destansı şiirlerinden gördükleri, onu bu yönde girişimlerde bulunmaya sevk etmiştir. Ebû Şâdî’nin bu yöndeki ilk girişimi 1924 senesinde yayımladığı Nekbetu Nâfârîn (Navarin Felaketi)'dir. O eserinde, Mehmed Ali Paşa döneminde Navarin Savaşı'nda Osmanlı hilafeti ve Türkleri savunan Mısır deniz kuvvetlerinin anısını ölümsüzleştirmiş, Mısır donanmasının üstlerinden ayrılmasından mağlup edinceye kadar ki durumunu canlı tasvirlerle tasvir etmiştir (Dayf, 1961: 152).

Ebû Şâdî, 1925 senesinde Mefheretu Reşîd (Reşit'in Övüncü) başlıklı yeni bir hikâye yazmış ve bu hikâyede 1807 senesinde Nisan savaşında bu şehirdeki günahkâr İngiliz düşmanlarına cevap veren Mısır kuvvetlerinin anısını ölümsüzleş̧irmiş̧tir. Bunu, Ebû Şâd’̂’nin hikâye ve şiirsel anlamda en az başarı sağladığı 'Abduh Bek ve Mehâ (Abduh Bey ve Meha) adında iki sosyal hikâyesi takip etmiştir (Dayf, 1961: 152).

Bunlardan ayrı olarak Ebû Şâdî, şiirinde hikâyeye yer vermiş hatta bazı eleştirmenler onu hikâyesel şiirin kurucusu kabul etmiştir (Islam ve Hossain, 2020: 13). Öte yandan Ebû Şâdî’nin şiirlerinde operaya da yer verdiğini görüyoruz. Opera, şiir ve tiyatrodan daha ziyade müziğe ve melodiye dayanır. Ve belki de bu yüzden onun operaları istenilen başarıyı yakalayamadı ve sanki o, bunu hissetmiş gibiydi. İlk operası olan İhsân'ın dipnotunda operanın tanımından, tarihçesinden, İtalyan, Fransız ve Alman ekollerinden genişçe bahsetmiştir. Sadece birinci ekolün şarkıya ve müziğe dayanan ekol olduğunu, ikinci ekolun edebî metinlere dayandığını, üçüncü ekolünse edebî metinlere fazla dayandığını ve onu temel aldığını dile getirmiştir. O, kendi opera sanatına dramatik bir değer kazandırmaya çalışarak son ekolu benimsemiştir. Seçtiği çizgide başarılı olduğuna hiç şüphe yoktur. Çünkü konularını bazen tarihten bazen de mitolojiden almıştır. Lakin gerek eserlerinin kurgusunda ve sanatsal unsurlarında, gerekse karakterlerinin 
yansımasında ve diyalogların kurgusunda arzu ettiği dramatik seviyeyi yakalayamamıştır. Aynı şekilde şiirinde de duru bir ritim yakalayamamıştır; çünkü şiiri, nağmenin gerektirdiği dinamizmden yoksundur. Bu bağlamda ilk yayımladığı eser Muğannâtu İhsân adlı eseridir. Bu eserde 1876 yılında çıkan Mısır-Habeş Savaşı sırasındaki olayları konu edinir. İhsan, subay olan, o savaşa katılan ve emsalsiz kahramanlık gösteren amcasının oğlu ile evlidir. Ne var ki eşi esir düşmüş, arkadaşları onun öldüğünü söylemiş; ancak eşi beş yıl sonra döndüğünde hanımının evlendiğini, hasta olduğunu ve son demlerini yaşadığını görmüştür. Hanımı onu gördüğünde yaşadığı büyük üzüntüden dolayı vefat etmiştir (Dayf, 1961: 152-153).

Ebû Şâdî, daha sonra dört bölüm olan ve Bin Bir Gece Masalları'ndan alıntıladığı Erdeşî̀ ve Hayâtu'n-Nufûs operasını yazmıştır. Daha sonra ise sembolik bir opera olan el-Âlihe 'yi nazmetmiştir. Bu operada bir filozof şairle sevgi tanrıçası ve şehvet-kuvvet tanrıçası arasındaki diyaloğa yer verir. Gerçekte bu diyalog, hayali bir diyalog olup dram çalışması değildir. Daha sonra ise Tedmur Kraliçesini konu edindiği ez-Zebâ operasını yazmıştır. Bu tarzda Ebû Şâdî, modern şiirde üretim gücü yüksek bir şairdi. Şu bir gerçek ki, onun şiir yeteneğinde bir eksiklik yoktu ve herhangi bir konuda düşündüğünü hemen yazabiliyordu. Ne var ki, hızlı ve aceleci oluşu çoğunlukla onun eserlerinin sanatsal değerini düşürüyordu (Dayf, 1961: 153).

\section{Sonuç}

1798 yılında Napolyon'un Mısır'1 işgalinden sonra Mısır'da yenileşme süreci başlamıştır. Devlet ricalinin de desteğiyle pek çok alanda yeni atılımlar olmuş ve bu duruma edebiyat ve şiir de ayak uydurmuştur. Modern dönem diye adlandırılan bu dönemde Arap şiiri, hem şekil hem de konu açısından gelişme göstermiş ve birtakım ekoller ortaya çıkmıştır. Bu ekollerden en önemlileri, Divan ekolü, Mehcer ekolü ve Apollo ekolüdür. Ahmed Zeki Ebû Şâdî öncülüğünde kurulan Apollo ekolü, genel anlamda Batı kültürünün etkisinde kalmış, romantizmi benimsemiş, benimsediği bu anlayışla 1930'lu yıllarda Modern Arap şiirine damgasını vurmuştur.

Apollo ekolünün kurucusu olan Ahmed Zeki Ebû Şâdî reformist bir anlayışla şiiri ele almış ve onu kuralcı bir anlayıştan kurtararak insanın ruhuna ve duygularına hitap eden yeni tarzda şiirler yayımlamış, duygularını özgürce dile getirmiştir. Arkadaşlarıyla birlikte çıkardığı Apollo dergisiyle modern Arap şiirine birçok yenilik getirmiştir. Onun, "serbest şiir" diye bilinen türü modern Arap şiirine kazandırmasıyla yenilikçi, şairleri romantizm akımıyla şiir yazmaya teşvik etmesiyle de öncü bir karakter olduğu muhakkaktır.

Ahmed Zeki Ebû Şâdî, her ne kadar daldan dala atlayarak eserlerinin manasında sığlığa düşmesine ve kendisiyle fikir ve hayal arasındaki farklı üslupları iyi kullanmasına engel olsa da şiirde getirdiği yenilik, göz ardı edilemeyecek kadar büyüktür. O, sadece şiirle yetinmemiş tıp, resim heykel, arıcıllk vb. başka alanlara da ilgi duyarak çok yönlü birisi olmuştur. Tüm bu gayretleri onu, modern Arap edebiyatının saygın şairleri arasına dâhil etmiştir. 


\section{Kaynaklar}

Adalar, D. (2007). Apollo grubu: Bir modern Arap şiiri ekolü. Ankara Üniversitesi Dil ve Tarih-Coğrafya Fakültesi Dergisi, 47(2). 61-81.

Brugman, J. (1984). An introduction to the history of modern Arabic literature in Egypt.

Ceylan, Z. (2015). Modern Arap edebiyatında ilk serbest şiir deneyimleri. Ankara Üniversitesi Dil ve Tarih-Coğrafya Fakültesi Dergisi, 55(1). 185-206.

Çakır, M. T. (2013). Modern Arap şiirinde Apollo ekolü, (Yayımlanmamış Yüksek Lisans Tezi). Atatürk Üniversitesi

Ḍayf, Ş. (1961). el-edebu'l- 'Arabiyyu'l-mu 'aṣır fì Mıșr. Dâru'l-Me ârif.

Ebû Şâdî, A. Z. (2013). el-yenbû‘. Müessesetu Hindavî li’t-Ta'lîm ve'ś-Sekââe.

Ebû Şâdî, A. Z. (2013). Endâu'l-fecr. Müessesetu Hindavî li’t-Ta'lîm ve’s -Sekâfe.

Ebû Şâdî, A. Z. (2013). Eşi ‘ ‘̂ ve zllâl. Müessesetu Hindavî li’t-Ta‘lîm ve’ś-Seḳ̂fe.

Ebû Şâdî, A. Z. (2013). eş-şu 'le. Müessesetu Hindavî li’t-Ta‘lîm ve’s s-Sekâafe.

Ebû Şâdî, A. Z. (2013). Fevḳa'l-'ubâb. Müessesetu Hindavî li’t-Ta'lîm ve’ś-

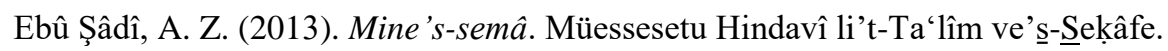

Ebû Şâdî, A. Z. (2017). Zeyneb. en-Naşîr Müessesetu Hindavî Si ay si.

el-Fâhûrî, H. (1986). Târîhu'l-edebi’l- 'Arabî el-edebu'l-ḥadîn. Dâru'l-Cîl.

el-Mu'avveş, S. (2011). el-edebu'l- 'Arabiyyu'l-ḥadîs. Dâru'l-Nahḍati'l-'Arabiyye.

Er, R. (2012). Çăgdaş Arap edebiyatı seçkisi. Vadi Yayınları.

ez-Zeyyât, A. H. (t.y.). Târîhuu'l-edebi'l- 'Arabî. Dâru Nahụati Miṣr.

Hafâcî, M. A. (1992). Dirâsât fi'l-edebi'l- 'Arabiyyi'l-hadị̂ ve Medârisih.

Heykel, A. (1994). Tațavvuru'l-edebi'l-ḥadîs fỉ Miṣr. Dâru'l-'Ulûm.

Kabbiş, A. (1971). Târîhu'ş-şi 'ri'l- 'Arabiyyi'l-ḥadîs. Dâru'l-Cîl.

Khouri, M. A. \& Algar, H. (1974). An anthology of modern Arabic poetry. University of California Press.

Savran, A. (1991). 19.Yüzyll Osmanlı döneminde yeni Arap edebiyatı. Atatürk Üniversitesi Fen-Edebiyat Fakültesi Yayını.

Islam, N. \& Hossain, A. (2020). The importance of the poems of Ahmed Zaki Abu Shadi: An analytical study. Sri Lankan Journal of Arabic and Islamic Studies, 3(2). 1-18.

Yalar, M. (2016). Ahmed Zekî Ebû Şâdî. Türkiye diyanet vakfı İslâm ansiklopedisi. ek1/(s. 371-372). TDV Yayınları. 
Yalar, M. (2003). Modern Arap şiiri. Arasta Yayınlar1.

Yanık, N. H. (1991). Mahmud Sâmî paşa el-Bârûdî hayatı, edebî kişiliği ve eserleri. (Yayımlanmamış Doktora Tezi). Atatürk Üniversitesi.

Zeydan, C. (2012). Meşâhîru'ş-şark. Müessesetu Hindavî Lit-Ta'lîm ve’ś-Seḳâfe. 